\title{
Molecular Characterization of Bacillus thuringiensis cyt Genes and Their Effect Against Fall Armyworm, Spodoptera frugiperda
}

\author{
Maria L. M. Costa ${ }^{1}$, Ubiraci G. P. Lana ${ }^{2}$, Emerson C. Barros ${ }^{2}$, Luciano V. Paiva ${ }^{1} \&$ Fernando H. Valicente ${ }^{2}$ \\ ${ }^{1}$ Department of Chemistry, Federal University of Lavras, Lavras, Brazil \\ ${ }^{2}$ Department of Biological Control, Brazilian Agricultural Research Corporation - Embrapa Maize and Sorghum, \\ Sete Lagoas, Brazil \\ Correspondence: Fernando H. Valicente, Department of Biological Control, Brazilian Agricultural Research \\ Corporation - Embrapa Maize and Sorghum, Rod MG 424 Km 45, Zona Rural, Sete Lagoas - MG, Brazil. Tel: \\ 55-31-3027-1284. E-mail: fernando.valicente@embrapa.br
}

Received: March 18, 2014 Accepted: May 4, 2014 Online Published: June 15, 2014

doi:10.5539/jas.v6n7p128 URL: http://dx.doi.org/10.5539/jas.v6n7p128

\begin{abstract}
Bacillus thuringiensis (Bt) endotoxins (Cyt and Cry) have been extensively explored for biological control of fall armyworm, Spodoptera frugiperda, an important pest in major corn-producing countries of America. Five hundred Bt isolates with different toxicities against $S$. frugiperda were characterized by PCR for the presence of $c y t$ genes (cyt1, cyt2, cyt1Aa, cyt1Ab, cyt2B and $c y t 2 B a)$, and the effect of insecticidal proteins Cry1Ba, Cry1Ca, Cry1Da and Cyt on $S$. frugiperda larvae were evaluated. Six isolates showed the presence of $c y t$ genes, three isolates harbored two gene families (cyt1 and cyt2), and three isolates harbored only one of the cyt gene families (cyt1 and cyt2). It was not possible to correlate the presence/absence of $c y t$ genes with toxicity against $S$. frugiperda. In this study, cyt genes were present in toxic and nontoxic isolates to this insect pest. Bioassays against S. frugiperda larvae showed that only Cry1Ca protein had toxicity, with $77.08 \%$ of mortality. Synergism among Cry and Cry proteins used in this study against $S$. frugiperda was not observed.
\end{abstract}

Keywords: Bacillus thuringiensis, cyt genes, entomopathogenic bacteria, Cry proteins, Cyt proteins

\section{Introduction}

Crop damage due to insect pests and diseases could account for up to 35\% of total losses (Pardo-Lopéz et al., 2013). The fall armyworm, Spodoptera frugiperda (J. E. Smith), is an important yield- and quality-limiting pest in major corn-producing countries of America (Storer et al., 2012). In tropical regions, the insecticide application is frequently needed to maintain the $S$. frugiperda population below economic thresholds as it is the main method of control. In recent years, microbial insecticides have become a viable alternative to control fall armyworms, and are considered a safe tool in Integrated Pest Management system (Valicente et al., 2010).

Bacillus thuringiensis (Bt) is a gram-positive spore-forming bacterium characterized by the production of insecticidal crystal bodies during the sporulation phase (Bravo et al., 2005). These crystals are predominantly comprised of one or more proteins, which are Crystal (Cry) and Cytolitic (Cyt) toxins. They are also called $\delta$-endotoxins and are highly specific to their target insect, are innocuous to humans, vertebrates and plants, and are completely biodegradable (Bravo et al., 2007).

Cry proteins are specifically toxic to different insect orders, such as Lepidoptera, Coleoptera, Hymenoptera, Diptera or nematodes (Bravo et al., 2005). In contrast, Cyt toxins show mainly dipteran specificity, being able to kill mosquitoes and black flies; they are not toxic to the major lepidopteran pests. Some Cyt toxins are able to kill coleopteran larvae, such as Cyt1Aa, which is toxic to Chrysomela scripta and also Cyt2Ca, which is toxic to Leptinotarsa decemlineata and Diabrotica spp. (Soberón et al., 2012). Therefore, Bt is a viable alternative for the control of insect pests in agriculture and of important human disease vectors (Bravo et al., 2005).

The isolation of native Bt strains has been done by several research groups (Valicente \& Barreto, 2003; Seifinejad et al., 2008). These Bt strain collections are an important source of new strains/genes with insecticidal properties involving molecular characterization, genetic variability between different Bt strains, screening of entomocidal Bt strains, and others (Bravo et al., 2007; Seifinejad et al., 2008; Hernández-Rodríguez et al., 2009). 
Cry toxins bind to specific protein receptors in the microvilli of the mosquito midgut cells (Bravo et al., 2007). In contrast, Cyt toxins do not bind to protein receptors but directly interact with membrane lipids inserting into the membrane and forming pores. However, synergism between Cyt and Cry toxins with some insecticidal proteins present in the mosquitocidal Bacillus thuringiensis subsp. israelensis (Bti) strain has been observed (Chang et al., 1993; Wu et al., 1994). Together, the Cyt1 A and Cryl1Aa proteins bind to the apical membrane in the same midgut region of the mosquito larvae, increasing the activity of Bti crystals (Pérez et al., 2005). To present, the molecular mechanism of synergism is unknown; however, the use of Cyt proteins combined with other mosquitocidal toxins could be used to delay the development of resistance and increase the activity of microbial insecticides (Wu et al., 2008).

This work aimed the molecular characterization of some Bt isolates with different toxicities against $S$. frugiperda for the presence of cyt genes and evaluated the effect of insecticidal proteins Cry1Ba, Cry1Ca, Cry1Da and Cyt on S. frugiperda larvae.

\section{Method}

\subsection{Bacterial Strains}

Five hundred Bt isolates obtained from different geographical regions from Brazil from Embrapa Maize and Sorghum Bt Collection were used. These isolates expressed different toxicities against $S$. frugiperda larvae (Valicente \& Barreto, 2003). In addition, Bt var. israelensis (Bti) and var. kurstaki (HD1) were kindly provided by São Paulo State University (UNESP/Jaboticabal, São Paulo, Brazil) and United States Department of Agriculture (Columbus, Ohio, USA), and were used as positive and negative controls, respectively. Bt isolates were grown accordingly as described in previous work (Valicente et al., 2010).

\subsection{Oligonucleotide Design}

Oligonucleotides previously described (Ibarra et al., 2003) were used (cytl and cyt2 genes) (Table 1). In addition, the specific primers of the four $c y t$ genes (cyt $1 A a, c y t 1 A b, c y t 2 B$ and $c y t 2 B a$ genes) were designed using Primer 3 (http://frodo.wi.mit.edu/primer3/) and Net Primer (http://www.premierbiosoft.com/netprimer/index.html) programs, and the Bt gene sequences were aligned using the Bt database (http://www.lifesci.sussex.ac.uk/ home/Neil_Crickmore/Bt/index.html). Variable regions within these genes were chosen to identify the gene subclasses.

Table 1. Characteristics of general and specific oligonucleotides for cyt1, cyt2, cyt1 Aa, cyt1Ab, cyt2B and cyt2Ba genes

\begin{tabular}{|c|c|c|c|c|}
\hline Primer pair & $\mathrm{T}^{\circ} \mathrm{C}$ Anneal. & Sequence $\left(5^{\prime}-3^{\prime}\right)$ & Gene(s) & NCBI \\
\hline cyt $1^{*}$ & 58 & $\begin{array}{l}\text { CCTCAATCAACAGCAAGGGTTATT(f) } \\
\text { TGCAAACAGGACATTGTATGTGTAATT(r) }\end{array}$ & $\begin{array}{l}\text { cyt } 1 A a \\
\text { cyt } 1 A b \\
\text { cyt } 1 B a\end{array}$ & $\begin{array}{l}\text { X03182 } \\
\text { X98793 } \\
\text { U37196 }\end{array}$ \\
\hline $\operatorname{cyt} 2 *$ & 56 & $\begin{array}{l}\text { ATTACAAATTGCAAATGGTATTCC(f) } \\
\text { TTTCAACATCCACAGTAATTTCAAATGC(r) }\end{array}$ & $\begin{array}{l}\text { cyt } 2 A a \\
\text { cyt } 2 B a \\
\text { cyt } 2 B b \\
\text { cyt } 2 C a\end{array}$ & $\begin{array}{l}\text { Z14147 } \\
\text { U52043 } \\
\text { U82519 } \\
\text { AAK50455 }\end{array}$ \\
\hline $\operatorname{cyt} 1 A a$ & 55 & $\begin{array}{l}\text { TGCATTAGTTCCCACTTCTACAGAT(f) } \\
\text { TACAGATCCACTTAATGCAACTCCT(r) }\end{array}$ & cyt $1 A a$ & EF656359.1 \\
\hline$c y t 1 A b$ & 52 & $\begin{array}{l}\text { AATGAAGCGTGGATTTTCTG(f) } \\
\text { CTGTGCGAATTTCAAGGATT(r) }\end{array}$ & $c y t 1 A b$ & X98793.1 \\
\hline $\operatorname{cyt} 2 B$ & 50 & $\begin{array}{l}\text { ATAATTCGGACGATGTAAG(r) } \\
\text { GGGTAGATTTATGGCAGTA(f) }\end{array}$ & $\begin{array}{l}c y t 2 B a \\
c y t 2 B c\end{array}$ & $\begin{array}{l}\text { GQ919041.1 } \\
\text { AJ251979.1 }\end{array}$ \\
\hline $\operatorname{cyt} 2 B a$ & 50 & $\begin{array}{l}\text { CAGGAACTCTTAATCAAAGTGTAAT(f) } \\
\text { CATCTACTTGAGGTTCTAAATTTGT(r) }\end{array}$ & $c y t 2 B a$ & GQ919041.1 \\
\hline
\end{tabular}

(f) forward; (r) reverse.

* Primers described by Ibarra et al. (2003). 


\subsection{Sample Preparation and PCR Analysis}

DNA isolation was performed by heat shock protocol (Bravo et al., 1998). Reactions consisted of $5 \mu$ DNA solution, $20 \mathrm{mM}$ Tris- $\mathrm{HCl}$ ( $\mathrm{pH} 8,4), 50 \mathrm{mM} \mathrm{KCl}, 2,5 \mathrm{mM} \mathrm{MgCl} 2,1 \mathrm{U}$ Taq DNA polimerase (Waterville, Maine, USA), $0,125 \mathrm{mM}$ de dNTPs and $0,4 \mu \mathrm{M}$ of each primer. Amplification was performed with the following steps: a single denaturation step of $2 \mathrm{~min}$ at $95{ }^{\circ} \mathrm{C}$, a step cycle program set for 30 cycles with each cycle consisting of denaturation at $95{ }^{\circ} \mathrm{C}$ for $1 \mathrm{~min}$, annealing at $50{ }^{\circ} \mathrm{C}(\mathrm{cyt} 2 \mathrm{~B}$ e cyt $2 \mathrm{Ba}), 52{ }^{\circ} \mathrm{C}(\mathrm{cyt} 1 \mathrm{Ab}), 55^{\circ} \mathrm{C}(\mathrm{cyt} 1 \mathrm{Aa}), 56{ }^{\circ} \mathrm{C}(\mathrm{cyt} 2)$ and $58{ }^{\circ} \mathrm{C}(\mathrm{cyt} l)$ for $1 \mathrm{~min}$, and extension at $72{ }^{\circ} \mathrm{C}$ for $1 \mathrm{~min}$, and a final extension step at $72{ }^{\circ} \mathrm{C}$ for $10 \mathrm{~min}$. A total of $20 \mu \mathrm{l}$ sample of each PCR mixture were electrophoresed on a $1.5 \%$ agarose gel in Tris-acetate-EDTA buffer (40 $\mathrm{mM}$ Tris-acetate, $1 \mathrm{mM}$ EDTA [pH 8.0]), stained with ethidium bromide $(1 \mu \mathrm{g} / \mathrm{mL})$ and pictured. PCR products for cyt genes were extracted from the agarose gel using the QIAquick Gel Extraction Kit (Qiagen, Valencia, CA, USA), according to the manufacturer's instructions. Each product was sequenced with Big Dye Terminator v3.1 kit (Applied Biosystems, Foster City, CA) to confirm the nature of the cyt genes. The sequences were analyzed and compared with the available information in the database Basic Local Alignment Search Tool (http://www.ncbi.nlm.nih.gov/blast/Blast.cgi).

\subsection{Bt Toxins Preparation}

The Cry1Ba, Cry1Ca and Cry1Da were obtained as recombinant proteins expressed in E. coli provided by Bacillus Stock Center (The Ohio State University, USA), and Cyt proteins were obtained by Bti strain provided by Unesp (São Paulo State University, Brazil).

Proteins were isolated as previously described (Valicente et al., 2010), with some modifications. Bacteria (E. coli) were grown at $37^{\circ} \mathrm{C}$ containing $100 \mu \mathrm{g} / \mathrm{mL}$ of ampicillin, and $28^{\circ} \mathrm{C}$ (Bti) in $250 \mathrm{ml} \mathrm{LB}$ medium, with continuous shaking at $150 \mathrm{rpm}$. One $\mathrm{mM}$ of IPTG was added in half of the treatments, and each protein had two replicates. After 4 days, the cultures were centrifuged at 10,000 rpm for $10 \mathrm{~min}$ and the pellet resuspended in $15 \mathrm{ml} 0.01 \%$ Triton solution. This step was repeated three times. Pellets composed of a mixture of spore-crystal were solubilized in $10 \mathrm{~mL}$ of solubilization buffer $(0.01 \%$ Triton, $10 \mathrm{mM} \mathrm{NaCl}$ and $50 \mathrm{mM}$ Tris- $\mathrm{HCl}, \mathrm{pH} 8.0)$. The mixture was centrifuged at $10,000 \mathrm{rpm}$ for $10 \mathrm{~min}$, and the pellet was resuspended in $10 \mathrm{~mL}$ of sodium bicarbonate

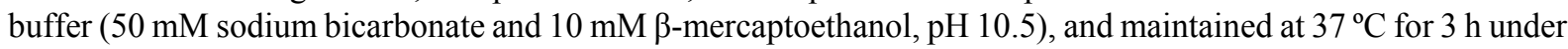
continuous shaking. Samples were centrifuged at $10,000 \mathrm{rpm}$ for $15 \mathrm{~min}$, and the pellet resuspended in $5 \mathrm{~mL}$ of 0.1 $\mathrm{M}$ Tris, $\mathrm{pH}$ 8.0, whereas the supernatant was transferred to a new tube and the $\mathrm{pH}$ adjusted to 8.0-8.5. The supernatant of the half treatments was treated with trypsin $\left(0.5 \mu \mathrm{g} \mu \mathrm{l}^{-1}\right)$ and incubated at $37^{\circ} \mathrm{C}$ for $2 \mathrm{~h}$ under continuous shaking, whereas the other half of the treatments were centrifuged without this step. The reaction was inactivated with $0.15 \mathrm{mM}$ PMSF (Phenyl Methyl Sulfonyl Fluoride). Samples were centrifuged at 10,000 rpm for $15 \mathrm{~min}$ and washed with distilled water. This step was repeated three times. SDS-PAGE analysis and observation of the crystals under a phase contrast microscope were performed to confirm the presence of proteins. The proteins were lyophilized, weighed and eluted in distilled sterile water and maintained at concentrations of $50 \mathrm{mg} / \mathrm{mL}$ and $100 \mathrm{mg} / \mathrm{mL}$.

\subsection{Insects Colony and Bioassays}

Two-day-old healthy $S$. frugiperda larvae were provided by the Biological Control Laboratory at Embrapa Maize and Sorghum Research Center (Sete Lagoas, Minas Gerais, Brazil). Each bioassay was composed of four replicates of 12 larvae each, and a total of 48 larvae per treatment.

In the first bioassay that aimed to evaluate the toxicity of Cry and Cyt proteins to S. frugiperda larvae isolated, trypsin-activated and non-activated $E$. coli clones were grown in LB medium with $1 \mathrm{mM}$ of IPTG, and the proteins were activated and non-activated with trypsin $\left(0.5 \mu \mathrm{g} \mu \mathrm{l}^{-1}\right)$. In the second bioassay that aimed to evaluate the synergism between the Cry (Cry1Ba, Cry1Ca and Cry1Da) and Cyt proteins (Bti strain) against $S$. frugiperda larvae, all proteins were treated with trypsin. The proteins were obtained as previously described (Valicente et al., 2010). The protein concentration used in first bioassay was $50 \mathrm{mg} / \mathrm{mL}$ of bacterial powder. In protein combinations (second bioassay), ratios were used, $1: 1$ and $1: 3$, corresponding to $50 \mathrm{mg} / \mathrm{mL}: 50 \mathrm{mg} / \mathrm{mL}$ and 50 $\mathrm{mg} / \mathrm{mL}: 150 \mathrm{mg} / \mathrm{mL}$, respectively, of each protein powder, with conditions adapted from a previous study (Pérez et al., 2005).

The larvae were transferred individually to $50 \mathrm{ml}$ disposable cups, each one containing $5 \mathrm{~g}$ of artificial diet $(123.6 \mathrm{~g} / \mathrm{L}$ cooked bean, $59.3 \mathrm{~g} / \mathrm{L}$ wheat germ, $38.0 \mathrm{~g} / \mathrm{L}$ brewer's yeast, $3.82 \mathrm{~g} / \mathrm{L}$ ascorbic acid, $2.36 \mathrm{~g} / \mathrm{L}$ Nipagin ${ }^{\circledR}$ M, $1.23 \mathrm{~g} / \mathrm{L}$ sorbic acid, $15.35 \mathrm{~g} / \mathrm{L}$ agar, $3.1 \mathrm{~g} / \mathrm{L}$ formaldehyde, $0.131 \mathrm{~mL} / \mathrm{L}$ fosforic acid, $1.3 \mathrm{~mL} / \mathrm{L}$ propionic acid) with $50 \mu \mathrm{l}$ of protein preparation. Larvae were kept at $25{ }^{\circ} \mathrm{C}, 70 \%$ humidity and $14 \mathrm{~h} / 10 \mathrm{~h}$ photophase. Mortality (\%) was evaluated determined 5 days after larvae toxin exposition. A negative control was composed of $5 \mathrm{~g}$ of artificial diet containing distilled water and Tween 20 . 


\subsection{Statistical Analysis}

The assumptions of normality of errors and homogeneity of variance were analyzed with the programs UNIVARIATE and GLM. The data were submitted to Kruskal-Wallis test at 5\% significance by the NPAIRWAY procedure of SAS version 9.2.

\section{Results}

\subsection{Screening of cyt Genes in Bt Collection}

Molecular analysis of PCR products showed that fragments with expected size were generated, and six strains out of 500 showed cyt genes. Three strains $(1168 \mathrm{C}, 1646 \mathrm{JAB}$ and $1656 \mathrm{JAB})$ showed two gene families (cytl and cyt2), and three strains only showed one of the $c y t$ families (257A with cyt1, LT09 and P283 with cyt2). Figures 1 and 2 shows the electrophoretic profiles of the strains using specific primers for $c y t 1$ and cyt2, respectively. The amplified fragments were confirmed by sequencing (Table 2).

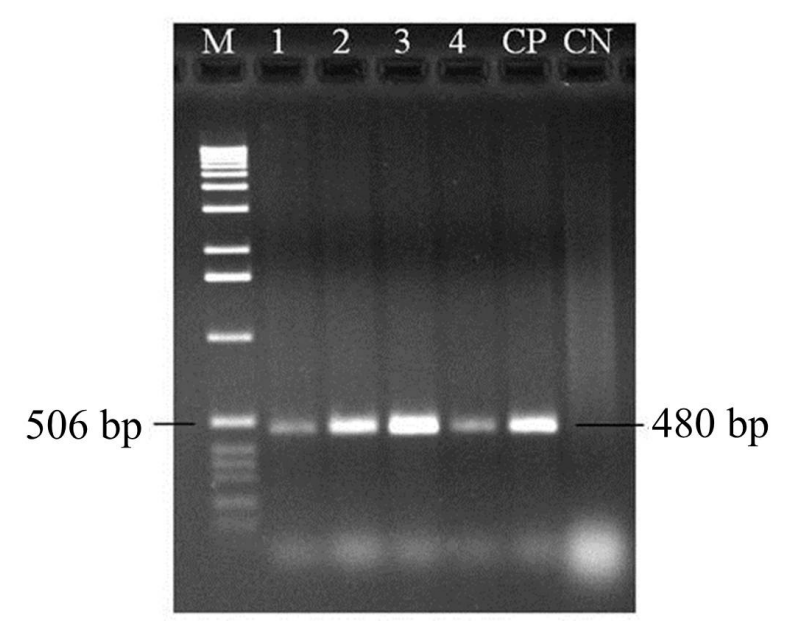

Figure 1. PCR products from Bt isolates with cyt 1 specific primers. Lanes: 1 - 257A, 2 - 1168C, 3 - 1646JAB, 4 1656JAB, CP - positive control (Bti) and CN - negative control (HD1). $\mathrm{M}$ - molecular weight marker (DNA Ladder $1 \mathrm{~Kb}$, Invitrogen ${ }^{\circledR}$ )

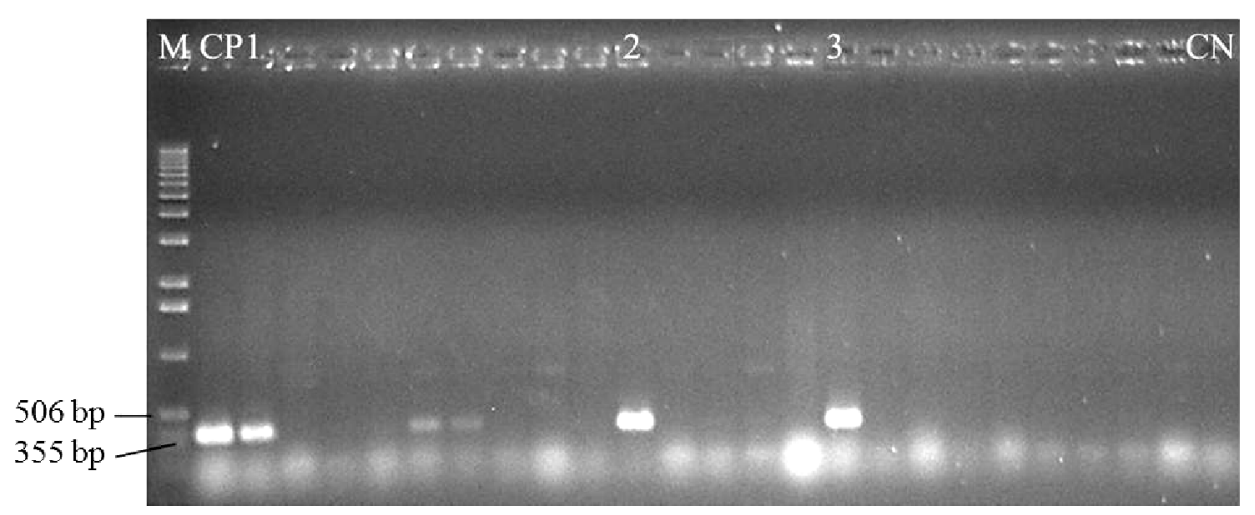

Figure 2. PCR products from Bt isolates with cyt2 specific primers. Lanes: 1 - 1646JAB, 2 - P238, 3 - LT09, CP positive control (Bti) and $\mathrm{CN}$ - negative control (HD1). $\mathrm{M}$ - molecular weight marker (DNA Ladder $1 \mathrm{~Kb}$, Invitrogen $($ )

Synthetic oligonucleotide primers were designed corresponding to the regions of no specific homology for the cyt 1 and $c y t 2$ families, and were used in these strains that harbored $c y t$ genes. All strains containing $c y t 1$ genes showed the gene cyt $1 \mathrm{Aa}$; only the strain $257 \mathrm{~A}$ also showed the cyt $1 \mathrm{Ab}$ gene. Out of 500 strains tested for $c y t 2$ genes, only one strain (P283) showed the cyt2Ba gene. 
The isolates containing cyt genes identified in this study showed different levels of toxicity against $S$. frugiperda (Valicente et al., 2000; Valicente \& Barreto, 2003; Valicente \& Fonseca, 2004; Valicente et al., 2010). Two isolates caused $100 \%$ mortality (isolates $1646 \mathrm{JAB}$ and $1656 \mathrm{JAB}$ ) and one caused $79 \%$ of larval mortality (strain $1168 \mathrm{C}$ ). Four isolates showed 0\% toxicity (isolates 257A, LT09, L7B8 and P283).

\subsection{Bioassays}

The first bioassay aimed to evaluate the toxicity of Cry and Cyt proteins to $S$. frugiperda larvae using each protein isolated, both trypsin- activated and non-activated. The wild-type Bti strain was used to provide the Cyt proteins and recombinant $E$. coli strains expressing Bt genes to recover the Cry proteins (Cry1Ba, Cry1Ca and Cry1Da). In Bti, the endotoxin parasporal body makes up approximately $30 \%$ of the dry weight of sporulated cells (Ibarra \& Federici, 1986). The concentration of toxins within the Bti parasporal body and percentage of the recombinant $E$. coli strains powder were estimated based on SDS-PAGE analyses. The protein concentration used in this experiment was $50 \mathrm{mg} / \mathrm{mL}$ of bacterial powder.

Table 2. BLAST analysis of Bt isolates using cyt1, cyt2, cyt1Aa, cyt1Ab and cyt2Ba primers

\begin{tabular}{|c|c|c|c|c|}
\hline Primer/Gene & Isolate/Strain & Acession $\mathrm{N}^{\circ}$ & E value & Max. Ident. \\
\hline \multirow[t]{5}{*}{ cyt 1} & Bti & DQ302752.2 & 0.0 & $99 \%$ \\
\hline & $257 \mathrm{~A}$ & DQ302752.2 & 0.0 & $97 \%$ \\
\hline & $1168 \mathrm{C}$ & DQ302752.2 & 0.0 & $93 \%$ \\
\hline & $1646 \mathrm{JAB}$ & DQ302752.2 & 0.0 & $98 \%$ \\
\hline & $1656 \mathrm{JAB}$ & DQ302752.2 & 0.0 & $98 \%$ \\
\hline \multirow[t]{6}{*}{ cyt 2} & Bti & DQ171939.2 & $2 e-166$ & $98 \%$ \\
\hline & $1168 \mathrm{C}$ & DQ171939.2 & $1 e-138$ & $93 \%$ \\
\hline & $1646 \mathrm{JAB}$ & DQ171939.2 & $2 e-155$ & $97 \%$ \\
\hline & $1656 \mathrm{JAB}$ & DQ171939.2 & $3 e-159$ & $97 \%$ \\
\hline & LT09 & DQ171939.2 & $2 \mathrm{e}-150$ & $96 \%$ \\
\hline & P283 & GQ9190041.1 & $1 e-137$ & $94 \%$ \\
\hline \multirow[t]{5}{*}{$\operatorname{cyt} 1 A a$} & Bti & DQ200984.1 & $3 e-62$ & $91 \%$ \\
\hline & $257 \mathrm{~A}$ & DQ200984.1 & $4 e-65$ & $89 \%$ \\
\hline & $1168 \mathrm{C}$ & DQ200984.1 & $2 e-62$ & $91 \%$ \\
\hline & $1646 \mathrm{JAB}$ & DQ200984.1 & $4 e-62$ & $87 \%$ \\
\hline & $1656 \mathrm{JAB}$ & DQ200984.1 & $2 e-62$ & $91 \%$ \\
\hline \multirow[t]{2}{*}{$c y t 1 A b$} & Bti & X98793.1 & $4 e-36$ & $83 \%$ \\
\hline & $257 \mathrm{~A}$ & X98793.1 & $1 e-48$ & $83 \%$ \\
\hline \multirow[t]{2}{*}{$\operatorname{cyt} 2 B^{*}$} & Bti & GQ919041.1 & $2 e-22$ & $86 \%$ \\
\hline & Bti & AJ251979.1 & $1 \mathrm{e}-020$ & $85 \%$ \\
\hline \multirow[t]{2}{*}{$c y t 2 B a$} & Bti & CQ919041.1 & $9 e-31$ & $90 \%$ \\
\hline & P283 & CQ919041.1 & $4 e-29$ & $89 \%$ \\
\hline
\end{tabular}

Bioassays data showed that only Cry1Ca powder was effective against $S$. frugiperda, with $77.08 \%$ of average mortality (Table 3), and the activation by trypsin increased the mortality of $S$. frugiperda larvae. The Cry $1 \mathrm{Ca}$ non-activated powder showed an average mortality of $18.75 \%$. The others two Cry proteins used (Cry1Ba and Cry $1 \mathrm{Da}$ ) showed low toxicity, with values lower than $8.3 \%$ mortality. The Cry1Ba protein was not toxic to $S$. frugiperda larvae with $0 \%$ of mortality, showing no statistical difference between the control treatment in both parameters evaluated. The Cry1Da protein caused a reduction in S. frugiperda larvae average weight, however without mortality. 
Table 3. Average mean ( \pm standard error) weights and mortality of S. frugiperda larvae subjected to Bt toxins. (T) - trypsin activated, $(*)$ - trypsin non-activated

\begin{tabular}{lcc}
\hline \multirow{2}{*}{ Treatment } & \multicolumn{2}{c}{ Means ( \pm standard error) } \\
\cline { 2 - 3 } & Weight of larvae (mg) & Mortality (\%) \\
\hline Water (Control) & $11.39 \pm 0.34 \mathrm{a}$ & $0.00 \pm 0.00 \mathrm{a}$ \\
Cry1Ba (*) & $11.85 \pm 0.23 \mathrm{ab}$ & $0.00 \pm 0.00 \mathrm{a}$ \\
Cry1Ba (T) & $11.08 \pm 0.64 \mathrm{ab}$ & $0.00 \pm 0.00 \mathrm{a}$ \\
Cry1Da (*) & $9.92 \pm 0.54 \mathrm{bc}$ & $0.00 \pm 0.00 \mathrm{a}$ \\
Cry1Da (T) & $9.51 \pm 0.44 \mathrm{bc}$ & $2.08 \pm 2.08 \mathrm{a}$ \\
Cry1Ca (*) & $2.55 \pm 0.36 \mathrm{de}$ & $18.75 \pm 9.24 \mathrm{bc}$ \\
Cry1Ca (T) & $0.62 \pm 0.23 \mathrm{f}$ & $77.08 \pm 11.47 \mathrm{~d}$ \\
\hline
\end{tabular}

Means followed by the same letter in columns are not significantly different by Kruskal-Wallis test $(\mathrm{p} \leq 0.05)$.

The second bioassay aimed to evaluate the synergism between the Cry (Cry1Ba, Cry1Ca and Cry1Da) and Cyt proteins (Bti strain) against $S$. frugiperda larvae. Two protein powder concentrations were used $(50 \mathrm{mg} / \mathrm{mL}$ and $100 \mathrm{mg} / \mathrm{mL}$ ) for each protein evaluated separately. In protein combinations, ratios were used, 1:1 and 1:3, corresponding to $50 \mathrm{mg} / \mathrm{mL}: 50 \mathrm{mg} / \mathrm{mL}$ and $50 \mathrm{mg} / \mathrm{mL}: 150 \mathrm{mg} / \mathrm{mL}$, respectively, of each protein powder.

The bioassay results showed that only treatments containing Cry1Ca protein was significantly different from control in both variables (Table 4). Higher average mortality was obtained when larvae were subjected to Cry1Ca protein isolated. The use of Cry $1 \mathrm{Ca}+\mathrm{Cry} 1 \mathrm{Da}(1: 1), \mathrm{Cyt}+\mathrm{Cry} 1 \mathrm{Ca}(1: 1)$ and $\mathrm{Cyt}+\mathrm{Cry} 1 \mathrm{Ca}(1: 3)$ protein combinations showed significant reduction in average mortality of $S$. frugiperda larvae, compared to Cry $1 \mathrm{Ca}$ protein isolated used in two concentrations $(50 \mathrm{mg} / \mathrm{mL}$ and $100 \mathrm{mg} / \mathrm{mL})$ with percentage of $56.25 \%, 22.92 \%$ and $22.92 \%$, respectively. No significant difference was observed in the toxicity of Cyt proteins isolated or in combination with Cry1Ba or Cry1Da proteins to $S$. frugiperda larvae in both parameters.

\section{Discussion}

The literature reports the high toxicity of Cyt proteins to Diptera (Guerchicoff et al., 2001; Wu et al., 2008; Mahalakshmi et al., 2012). The focus of this study was to investigate the distribution of $c y t$ genes in the native $\mathrm{Bt}$ isolates and its toxicity to $S$. frugiperda larvae. The synergism between the Cry and Cyt proteins was also assessed.

The investigation of $c y t$ genes in native Bt isolates shows that the cyt genes are not a common in the Bt strains, compared to Lepidoptera-specific toxins frequency. In this study, among the $500 \mathrm{Bt}$ isolates, six (1.2\%) harbored $c y t$ genes. In a previous study performed by Costa et al. (2010) 1073 isolates were evaluated as the presence of dipteran specific genes. The frequency of cyt1Aa, cyt1Ab an cyt2Aa genes was $1.58 \%, 0,65 \%$ and $1,11 \%$, respectively. Wu et al. (2008) observed only three isolates containing cyt genes investigating the presence of $c y t$ genes in 143 isolates from soil samples of China using two pairs of primers (cyt1 and cyt2 gene). The identification of $B$. thuringiensis delta-endotoxin genes by PCR has proven to be a very useful method for strain characterization isolated worldwide and its use as a preliminary selection step that offers many advantages in terms of rapidity and reproducibility (Porcar \& Juárez-Pérez, 2003). Thus, from the rapid identification of potential genes, its toxic activity has to be tested directly by bioassay against a series of insect species.

In present study, there was no correlation between the presence/absence of $c y t$ genes and toxicity of Bt isolate to $S$. frugiperda, since these genes were present in effective and not effective isolates. 
Table 4. Means ( \pm standard error) of larval weight and mortality of S. frugiperda subjected to toxins from Bt

\begin{tabular}{lcc}
\hline \multirow{2}{*}{ Treatment } & \multicolumn{2}{c}{ Means $( \pm$ standard error) } \\
\cline { 2 - 3 } & Weight of larvae $(\mathrm{mg})$ & Mortality (\%) \\
\hline Water (control) & $12.39 \pm 0.19 \mathrm{a}$ & $0.00 \pm 0.00 \mathrm{a}$ \\
Cyt $(50 \mathrm{mg} / \mathrm{mL})$ & $12.42 \pm 0.10 \mathrm{a}$ & $0.00 \pm 0.00 \mathrm{a}$ \\
Cyt $(100 \mathrm{mg} / \mathrm{mL})$ & $13.10 \pm 0.30 \mathrm{a}$ & $0.00 \pm 0.00 \mathrm{a}$ \\
Cry1Ba $(50 \mathrm{mg} / \mathrm{mL})$ & $12.65 \pm 0.10 \mathrm{a}$ & $0.00 \pm 0.00 \mathrm{a}$ \\
Cry1Ba $(100 \mathrm{mg} / \mathrm{mL})$ & $12.08 \pm 0.28 \mathrm{a}$ & $0.00 \pm 0.00 \mathrm{a}$ \\
Cry1Da $(50 \mathrm{mg} / \mathrm{mL})$ & $12.41 \pm 0.10 \mathrm{a}$ & $0.00 \pm 0.00 \mathrm{a}$ \\
Cry1Da $(100 \mathrm{mg} / \mathrm{mL})$ & $11.35 \pm 0.27 \mathrm{a}$ & $0.00 \pm 0.00 \mathrm{a}$ \\
Cyt+Cry1Ba $(1: 1)$ & $13.82 \pm 0.89 \mathrm{a}$ & $0.00 \pm 0.00 \mathrm{a}$ \\
Cyt+Cry1Ba $(1: 3)$ & $13.37 \pm 0.43 \mathrm{a}$ & $0.00 \pm 0.00 \mathrm{a}$ \\
Cyt+Cry1Da $(1: 1)$ & $13.33 \pm 0.35 \mathrm{a}$ & $0.00 \pm 0.00 \mathrm{a}$ \\
Cyt+Cry1Da $(1: 3)$ & $13.79 \pm 0.26 \mathrm{a}$ & $0.00 \pm 0.00 \mathrm{a}$ \\
Cry1Ba+Cry1Da $(1: 1)$ & $13.11 \pm 0.19 \mathrm{a}$ & $0.00 \pm 0.00 \mathrm{a}$ \\
Cyt+Cry1Ca $(1: 1)$ & $3.21 \pm 0.26 \mathrm{~b}$ & $22.92 \pm 5.33 \mathrm{~b}$ \\
Cyt+Cry1Ca (1:3) & $2.26 \pm 0.29 \mathrm{~b}$ & $22.92 \pm 5.68 \mathrm{~b}$ \\
Cry1Ca+Cry1Da $(1: 1)$ & $2.62 \pm 0.09 \mathrm{~b}$ & $56.25 \pm 2.30 \mathrm{c}$ \\
Cry1Ca+Cry1Ba $(1: 1)$ & $2.58 \pm 0.20 \mathrm{~b}$ & $70.83 \pm 3.11 \mathrm{~d}$ \\
Cry1Ca $(50 \mathrm{mg} / \mathrm{mL})$ & $2.16 \pm 0.48 \mathrm{~b}$ & $75.00 \pm 5.89 \mathrm{~d}$ \\
Cry1Ca $(100 \mathrm{mg} / \mathrm{mL})$ & $2.13 \pm 0.25 \mathrm{~b}$ & $77.08 \pm 2.30 \mathrm{~d}$ \\
\hline
\end{tabular}

Means followed by the same letter in columns are not significantly different by Kruskal-Wallis test $(\mathrm{p} \leq 0.05)$.

All strains harboring cyt1 genes also contained cyt1Aa gene. Identification that the subclass level of the genes presents on Bt strains proves useful due to the high specificity of the $\delta$-endotoxin to insect groups. The Cyt1Aa protein is nontoxic or less toxic for Aedes aegypti, Anopheles stephensi, and Culex pipiens, but synergizes the toxic effect of Cry proteins, as Cry11Aa (Oestergaard et al., 2007).

It is known that the Cyt proteins are found particularly, but not exclusively, among strains that display antidipteran activity (Wu et al., 2008). However, cyt genes were identified in Bt strains toxic to insects of the orders Lepidoptera and Coleoptera (Guerchicoff et al., 1997, 2001). Our results show the need for additional bioassays involving other groups of insects such as $S$. frugiperda, in order to elucidate the actual role of these genes against this group of insects and its toxicity.

The strains used in this study were previously characterized for cryl genes (Valicente et al., 2010), and the presence of both cyt and cry genes in the strains used in this study suggest a source for new investigations involving synergism, as its possible effect against $S$. frugiperda and other lepidopteran insetcs. Previous studies have shown that the Cyt proteins have no toxicity alone, acting on the cell membrane of the insect gut synergistically with Cry proteins, and many authors suggest that the Cyt proteins can interact synergistically with one or more of the Cry proteins thereby increasing toxicity from 5- to 20-fold (Wu \& Chang, 1985; Wu et al., 1994). Pérez et al. (2005) observed that synergism between Cyt1 Aa and the Cry proteins of Bti, and the activity of the Bti crystals is much higher than that of the isolated proteins.

In our study, we tested the ability of Cyt proteins to increase the toxic activity of Cry proteins toxic and nontoxic to S. frugiperda larvae as a tool for suppression of insect resistance. The bioassay analysis demonstrated that only Cry1Ca protein was effective against $S$. frugiperda larvae. The effectiveness of Cry1 proteins against lepidopteran larvae have been shown in several studies (Aranda et al., 1996; Bravo et al., 2007; Hernández-Martínez et al., 2008). Aguiar et al. (2006) constructed a truncated version of crylCa gene from B. thuringiensis strain 1644 inserted into the baculovirus Ac-MNPV that showed toxicity to second instar S. frugiperda larvae. 
Positive synergism was not observed among the proteins evaluated against $S$. frugiperda larvae. There was no increase in toxicity when Cyt and Cry proteins were used together. These results suggest the use of new protein combinations in future studies. Synergism can lead to a reduction in the amount of Bt required for the use in insect pests control, increase the spectrum of action and reduce the evolution of resistance of these insects (Liu \& Tabashnik, 1997).

The response of different species of insects to Bt proteins due to intrinsic differences of each specie, where different toxicity patterns can be observed, even within the same Order. Santos et al. (2009) showed that Cry1A and Cry1 Ab proteins caused the highest mortality against $S$. frugiperda. López-Pazos et al. (2010) reported a low toxicity of the Cry1Ba toxin against Tecia solanivora (Lepidoptera), and it was also observed in this study. However, Hernández-Martínez et al. (2008) obtained a high mortality when S. exigua was tested with Cry1Da protein, however, this toxicity was not observed in our studies. This difference in larval mortality may be related to the use of S. frugiperda.

This study was able to detect cyt genes in Bt isolates tested, contributing to the Bt Collection cataloging. The discovery of cyt genes enables for their use in future studies of insect pests. The development of insect-resistance and cross-resistance to $\mathrm{Bt}$ toxins in target insects threatens the future use of these proteins in insect control. Thus, the constant search for effective Bt strains and genes against $S$. frugiperda and other insect pests is useful for managing resistance to insects and in the control of vectors of human diseases.

\section{Acknowledgements}

To CAPES (Coordenação de Aperfeiçoamento de Pessoal de Nível Superior) for fellowships and research support, and FAPEMIG (Fundação de Amparo à Pesquisa do Estado de Minas Gerais) for research support.

\section{References}

Aguiar, R. W. S., Martins, E. S., Valicente, F. H., Carneiro, N. P., Batista, A. C., Melatti, V. M., ... Ribeiro, B. M. (2006). A recombinant truncated Cry1Ca protein is toxic to lepidopteran insects and forms large cuboidal crystals in insect cells. Current Microbiology, 53(4), 287-292. http://dx.doi.org/10.1007/s00284-005-0502-3

Aranda, E., Sanchez, J., Peferoen, M., Güereca, L., \& Bravo, A. (1996). Interactions of Bacillus thuringiensis crystal proteins with the midgut epithelial cells of Spodoptera frugiperda (Lepidoptera: Noctuidae). Journal of Invertebrate Pathology, 68(3), 203-212. http://dx.doi.org/10.1006/jipa.1996.0087

Bravo, A., Gill, S. S., \& Soberón, M. (2005). Bacillus thuringiensis mechanisms and use. In L. I. Gilbert, K. Iatrou, \& S. S. Gill (Eds.), Comprehensive molecular insect science (pp.175-206). Amsterdam: Elsevier B.V. http://dx.doi.org/10.1016/B0-44-451924-6/00081-8

Bravo, A., Gill, S. S., \& Soberón, M. (2007). Mode of action of Bacillus thuringiensis Cry and Cyt toxins and their potential for insect control. Toxicon, 49(4), 423-435. http://dx.doi.org/10.1016/j.toxicon.2006.11.022

Bravo, A., Sarabia, S., Lopez, L., Ontiveros, H., Abarca, C., Ortiz, A., ... Quintero, R. (1998). Characterization of cry genes in a Mexican Bacillus thuringiensis strain collection. Applied and Environmental Microbiology, 64(12), 4965-4972.

Chang, C., Yu, Y. M., Dai, S. M., Law, S. K., \& Gill, S. S. (1993). High-level cryIVD and cytA gene expression in Bacillus thuringiensis does not require the 20-kilodalton protein, and the coexpressed gene products are synergistic in their toxicity to mosquitoes. Applied and Environmental Microbiology, 59(3), 815-821.

Costa, J. R. V., Rossi, J. R., Marucci, S. C., Alves, E. C. C., Volpe, H. X. L., Ferraudo, A. S., ... Desidério, J. A. (2010). Atividade tóxica de isolados de Bacillus thuringiensis a larvas de Aedes aegypti (L.) (Diptera: Culicidae). Neotropical Entomology, 39(5), 757-766. http://dx.doi.org/10.1590/S1519-566X2010000500015

Guerchicoff, A., Delecluse, A., \& Rubinstein, C. P. (2001). The Bacillus thuringiensis cyt genes for hemolytic endotoxins constitute a gene family. Applied and Environmental Microbiology, 67(3), 1090-1096. http://dx.doi.org/10.1128/AEM.67.3.1090-1096.2001

Guerchicoff, A., Ugalde, R. A., \& Rubinstein, C. P. (1997). Identification and characterization of a previously undescribed cyt gene in Bacillus thuringiensis subsp. israelensis. Applied and Environmental Microbiology, 63(7), 2716-2721.

Hernández-Martínez, P., Ferré, J., \& Escriche, B. (2008). Susceptibility of Spodoptera exigua to 9 toxins from Bacillus thuringiensis. Journal of Invertebrate Pathology, 97(3), 245-250. http://dx.doi.org/10.1016/j.jip.2007.11.001 
Hernández-Rodríguez, C. S., Boets, A., Van Rie, J., \& Ferré, J. (2009). Screening and identification of vip genes in Bacillus thuringiensis strains. Journal of Applied Microbiology, 107(1), $219-225$. http://dx.doi.org/10.1111/j.1365-2672.2009.04199.x

Ibarra, J. E., \& Federici, B. A. (1986). Parasporal bodies of Bacillus thuringiensis subsp. morrisoni (PG-14) and Bacillus thuringiensis subsp. israelensis are similar in protein composition and toxicity. FEMS Microbiology Letters, 34(1), 79-84. http://dx.doi.org/10.1111/j.1574-6968.1986.tb01353.x

Ibarra, J., Rincón, M. C., Ordúz, S., Noriega, D., Benintende, G., Monnerat, R., ... Bravo, A. (2003). Diversity of Bacillus thuringiensis strains from Latin America with insecticidal activity against different mosquito species. Applied and Environmental Microbiology, 69(9), 5269-5274. http://dx.doi.org/10.1128/AEM.69.9.5269-5274.2003

Liu, Y. B., \& Tabashnik, B. E. (1997). Synergism of Bacillus thuringiensis by ethylenediamine tetraacetate in susceptible and resistant larvae of diamondback moth (Lepidoptera: Plutellidae). Journal of Economic Entomology, 90(2), 287-292.

López-Pazos, S. A., Rojas Arias, A. C., Ospina, S. A., \& Cerón, J. (2010). Activity of Bacillus thuringiensis hybrid protein against a lepidopteran and a coleopteran pest. FEMS Microbiology Letters, 302(2), 93-98. http://dx.doi.org/10.1111/j.1574-6968.2009.01821.x

Mahalakshmi, A., Sujatha, K., Kani, P., \& Shenbagarathai, R. (2012). Distribution of cry and cyt genes among indigenous Bacillus thuringiensis isolates with mosquitocidal activity. Advances in Microbiology, 2(3), 216-226. http://dx.doi.org/10.4236/aim.2012.23026

Oestergaard, J., Ehlers, R. U., Martíniez-Ramírez, A. C., \& Real, M. D. (2007). Binding of Cyt1Aa and Cry11Aa Toxins of Bacillus thuringiensis serovar israelensis to brush border membrane vesicles of Tipula paludosa (Diptera: Nematocera) and subsequent pore formation. Applied and Environmental Microbiology, 73(11), 3623-3629. http://dx.doi.org/10.1128/AEM.01056-06

Pardo-Lopéz, L., Soberón, M., \& Bravo, A. (2013). Bacillus thuringiensis insecticidal three-domain Cry toxins: mode of action, insect resistance and consequences for crop protection. FEMS Microbiology Reviews, 37(1), 3-22. http://dx.doi.org/10.1111/j.1574-6976.2012.00341.x

Pérez, C., Fernández, L. E., Sun, J., Folch, J. L., Gill, S. S., Soberón, M., \& Bravo, A. (2005). Bacillus thuringiensis subsp. israelensis Cyt1Aa synergizes Cry11Aa toxin by functioning as a membrane-bound receptor. PNAS of United States of America, 102(51), 18303-18308. http://dx.doi.org/10.1073/pnas.0505494102

Porcar, M., \& Juárez-Pérez, V. (2003). PCR-based identification of Bacillus thuringiensis pesticidal crystal genes. FEMS Microbiology Reviews, 26(5), 419-432. http://dx.doi.org/10.1111/j.1574-6976.2003.tb00624.x

Santos, K. B., Neves, P., Meneguim, A. M., Santos, R. B., Santos, W. J., Villas-Boas, G., ... Monnerat, R. (2009). Selection and characterization of the Bacillus thuringiensis strains toxic to Spodoptera eridania (Cramer), Spodoptera cosmioides (Walker) and Spodoptera frugiperda (Smith) (Lepidoptera: Noctuidae). Biological Control, 50(2), 157-163. http://dx.doi.org/10.1016/j.biocontrol.2009.03.014

Seifinejad, A., Salehi Jouzani, G. R., Hosseinzadeh, A., \& Abdmishani, C. (2008). Characterization of Lepidoptera-active cry and vip genes in Iranian Bacillus thuringiensis strain collection. Biological Control, 44(2), 216-226. http://dx.doi.org/10.1016/j.biocontrol.2007.09.010

Soberón, M., Rodriguez-Almazán, C., Muñóz-Garay, C., Pardo-López, L., Porta, H., \& Bravo, A. (2012). Bacillus thuringiensis Cry and Cyt mutants useful to counter toxin action in specific environments and to overcome insect resistance in the field. Pesticide Biochemistry and Physiology, 104(2), 111-117. http://dx.doi.org/10.1016/j.pestbp.2012.05.003

Storer, N. P., Kubiszak, M. E., Ed King, J., Thompson, G. D., \& Santos, A. C. (2012). Status of resistance to Bt maize in Spodoptera frugiperda: Lessons from Puerto Rico. Journal of Invertebrate Pathology, 110(3), 294-300. http://dx.doi.org/10.1016/j.jip.2012.04.007

Valicente, F. H., \& Barreto, M. R. (2003). Bacillus thuringiensis survey in Brazil: geographical distribution and insecticidal activity against Spodoptera frugiperda (J.E. Smith) (Lepidoptera: Noctuidae). Neotropical Entomology, 32(4), 639-644. http://dx.doi.org/10.1590/S1519-566X2003000400014

Valicente, F. H., \& Fonseca, M. M. (2004). Susceptibilidade da lagarta-do-cartucho do milho, Spodoptera frugiperda, a diferentes isolados de Bacillus thuringiensis. Revista Brasileira de Milho e Sorgo, 3(1), 21-29. 
Valicente, F. H., Barreto, M. R., Vasconcelos, M. J. V., Figueiredo, J. E. F., \& Paiva, E. (2000). Identificação através de PCR dos genes cryI de cepas de Bacillus thuringiensis Berliner eficientes contra a lagarta do cartucho, Spodoptera frugiperda (J.E.Smith) (Lepidoptera: Noctuidae). Anais da Sociedade Entomológica do Brasil, 29(11), 147-153. http://dx.doi.org/10.1590/S0301-80592000000100018

Valicente, F. H., Picoli, E. A. T., Vasconcelos, M. J. V., Carneiro, N. P., Carneiro, A. A., Guimarães, C. T., \& Lana, U. G. (2010). Molecular characterization and distribution of Bacillus thuringiensis cryl genes from Brazilian strains effective against the fall armyworm, Spodoptera frugiperda. Biological Control, 53, 360-366. http://dx.doi.org/10.1016/j.biocontrol.2010.02.003

Wu, D., \& Chang, F. N. (1985). Synergism in mosquitocidal activity of 26 and $65 \mathrm{kDa}$ proteins from Bacillus thuringiensis subsp. israelensis crystal. FEBS Letters, 190(2), 232-236. http://dx.doi.org/10.1016/0014-5793(85)81290-4

Wu, D., Johnson, J. J., \& Federici, B. A. (1994). Synergism of mosquitocidal toxicity between CytA and CryIVD proteins using inclusions produced from cloned genes of Bacillus thuringiensis. Molecular Microbiology, 13(6), 965-972. http://dx.doi.org/10.1111/j.1365-2958.1994.tb00488.x

Wu, Y., Gao, M., Dai, S., Yi, D., \& Fan, H. (2008). Investigation of the cyt gene in Bacillus thuringiensis and the biological activities of Bt isolates from the soil of China. Biological Control, 47(3), 335-339. http://dx.doi.org/10.1016/j.biocontrol.2008.08.020

\section{Copyrights}

Copyright for this article is retained by the author(s), with first publication rights granted to the journal.

This is an open-access article distributed under the terms and conditions of the Creative Commons Attribution license (http://creativecommons.org/licenses/by/3.0/). 